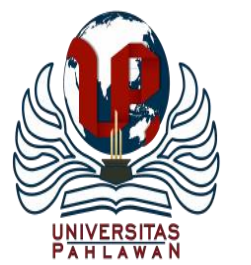

Edukatif : Jurnal Ilmu Pendidikan Volume 3 Nomor 4 Tahun 2021 Halm 1936 - 1944

EDUKATIF: JURNAL ILMU PENDIDIKAN

Research \& Learning in Education

https:/ledukatif.org/index.php/edukatif/index

\title{
Pengaruh Pembelajaran Daring Berbasis Google Classroom terhadap Hasil Belajar Mahasiswa Pendidikan Biologi
}

\author{
Rahmatia Thahir \\ Universitas Muhammadiyah Makassar, Indonesia \\ E-mail : rahmatiah.thahir@ unismuh.ac.id
}

\begin{abstract}
Abstrak
Tujuan penelitian ini adalah untuk mengetahui pengaruh pembelajaran daring berbasis Google Classroom terhadap hasil belajar mahasiswa pendidikan biologi Universitas Muhammadiyah Makassar. Jenis penelitian ini adalah pre experiment dengan desain penelitian yaitu One Group Pretest Posttest Design. Populasi dalam penelitian adalah seluruh mahasiswa semester VI program studi Pendidikan biologi Angkatan 2018 sebanyak 55 orang. Sampel penelitian ini adalah sebanyak 20 orang, pemilihan sampel menggunakan Teknik purposive sampling. Variabel bebas dalam penelitian ini adalah pembelajaran daring sedangkan variable terikatnya adalah hasil belajar mahasiswa. Instrument penelitian yang digunakan adalah soal essai sebanyak 10 nomor. Teknik pengumpulan data dilakukan dengan pemberian pretest dan posttest. Kemudian data yang telah diperoleh kemudian dianalisis secara statistik deskriptif dan dan statistik inferensial dengan bantuan program SPSS versi 24. Hasil penelitian menunjukkan nilai rata-rata pretest sebesar 55 sedangkan nilai rata-rata pada saat posttest sebesar 80. Hasil uji hipotesis dengan menggunakan analisis Independent Sample T Test dan diperoleh nilai signifikasi $p=0,001<\alpha=0,05$. Dengan demikian dapat disimpulkan bahwa ada pengaruh pembelajaran daring berbasis Google Classroom terhadap hasil belajar mahasiswa.
\end{abstract}

Kata Kunci: Pembelajaran daring, Google Classroom, hasil belajar.

\begin{abstract}
This study aimed to determine the effect of online learning based Google Classroom on student learning outcomes of biology education at University of Muhammadiyah Makassar. This research is a pre-experimental design, namely One Group Pretest Posttest Design. The population in study were all students of sixth semester of 2018 Biology Education with a total of 55 people. The sample this research is students many as 20 people, the sample selection using purposive sampling technique. The independent variable is online learning and dependent variable is student learning outcomes. The research instrument used was an essay question of 10 numbers. The data collection technique was done by giving pretest and posttest. The data has been obtained was analyzed descriptively and statistically inferential with the help of the SPSS 24 program. The results average value of the pretest was 55 and posttest was 80. Hypothesis testing using Independent Sample T Test and obtained a significance value of $p=0.001<\alpha=0.05$. It can be concluded that there is an effect of online learning based on Google Classroom on student learning outcomes.
\end{abstract}

Keywords: Online learning, Google Classroom, learning outcome.

Copyright (c) 2021 Rahmatia Thahir

$\square$ Corresponding author

Email : rahmatiah.thahir@unismuh.ac.id

DOI : https://doi.org/10.31004/edukatif.v3i4.1123

ISSN 2656-8063 (Media Cetak)

ISSN 2656-8071 (Media Online) 
1937 Pengaruh Pembelajaran Daring Berbasis Google Classroom terhadap Hasil Belajar Mahasiswa Pendidikan Biologi-Rahmatia Thahir

DOI: https://doi.org/10.31004/edukatif.v3i4.1123

\section{PENDAHULUAN}

Surat edaran Dirjen Dikti Kementerian Pendidikan dan Kebudayaan Nomor 1 Tahun 2020 tentang pencegahan penyebaran corona virus disease (COVID-19) di perguruan tinggi. Berisi tentang himbauan agar perguruan tinggi melaksanakan pembelajaran jarak jauh sesuai dengan kondisi masing-masing, dan mahasiswa disarankan melakukan pembelajaran dari rumah. Berdasarkan kejadian yang terjadi di Indonesia saat ini akibat pandemi COVID-19 maka kegiatan pembelajaran menjadi terhambat karena kegiatan belajar di sekolah maupun universitas ditiadakan. Termasuk kegiatan belajar mengajar di kampus Universitas Muhammadiyah Makassar yang sejak awal pandemi sampai sekarang melaksanakan pembelajaran daring. Hal ini menyebabkan pendidik atau dosen kebingungan dalam memilih aplikasi pembelajaran daring yang efektif untuk menyampaikan materi yang harus sesuai dengan jadwal kegiatan program semester karena kegiatan pembelajaran di dalam kelas ditiadakan. Dengan adanya teknologi sebagai penunjang dalam pembelajaran, pemanfaatan teknologi sebagai pendukung proses belajar secara daring mampu menjawab tantangan guru di abad 21 dalam menyampaikan materi yang harus sesuai jadwal kegiatan program semester (Su'uga et al., 2020).

Pendidikan mengimplemetasikan teknologi informasi sebagai salah satu bagian dari kurikulum yang harus memiliki kecapakan saat ini, karena proses belajar mengajar selain menggunakan ruang kelas fisik dengan peralatan elektronik dan dilaksanakan pula pembelajaran daring (dalam jaringan). Pendidik juga memperkenalkan teknologi perangkat lunak berbasis web untuk berbagi pengetahuan apabila peserta didik dan pendidik tidak berada pada waktu dan tempat yang sama. Di jaman kemajuan teknologi saat ini, media yang dapat digunakan sangatlah banyak seperti media cetak, media elektronik, dan media Pendidikan yang memang dipersiapkan untuk memudahkan pembelajaran. Media pembelajaran dengan sentuhan teknologi informasi dan komunikasi muncullah sebuah konsep yang dikenal dengan konsep E-learning atau konsep pembelajaran daring. Pembelajaran ini dapat digunakan siapa saja (everyone), dimana saja (everywhere), dan kapan saja (everytime). Pembelajaran yang menitik beratkan pada efesiensi sebuah proses belajar mengajar (Nande \& Irman, 2021). Dalam hal ini bisa menggunakan aplikasi yaitu google classroom yang bermanfaat untuk meningkatkan pengorganisasian peningkatan komunikasi, terjangkau, dan aman (Durahman, 2020).

Transformasi layanan dari yang konvensional menjadi layanan digital yang cepat, fleksibel, efektif, dan efisien menjadi tuntutan masa sekarang. Pendidikan harus mampu merespon situasi seperti ini. Kajian serius berkelanjutan perlu untuk selalu dilakukan untuk mewujudkan layanan prima perguruan tinggi di era globalisasi di masa pandemi. Oleh karena itu memerlukan pembelajaran daring untuk mendukung hal itu. Pembelajaran daring yang dilakukan secara online merupakan salah satu solusi dari berbagai masalah yang terkait dengan hasil belajar konitif peserta didik (Nurdiyanti \& Jannah, 2021). Jika penggunaan media yang tepat akan meningkatkan perhatian mahasiswa pada topik yang dipelajari, dengan bantuan media aplikasi diharapkan tidak mengurangi minat dan motivasi mahasiswa, lebih berkonsentrasi dalam belajar dan diharapkan proses pembelajaran menjadi lebih baik sehingga pada akhirnya meningkatkan prestasi belajar maka dibutuhkan alat bantu atau aplikasi yanh dapat mendukung proses pembelajaran salah satunya yaitu aplikasi google classroom. Selain itu fitur-fitur dalam aplikasi ini sangat kaya sehingga dapat menunjang berbagai kegiatan baik itu penyampaian materi maupun evaluasi untuk mengukur sejauh mana keberhasilan dalam proses pembelajaran.

Salah satu cara yang dapat digunakan untuk melakukan proses pembelajaran secara daring adalah dengan menggunakan google classroom. Melalui google classroom diasumsikan bahwa tujuan pembelajaran akan lebih mudah direalisasikan dan sarat makna. Google classroom adalah aplikasi yang dibuat oleh google yang bertujuan untuk membantu dosen dan mahasiswa apabila keduanya berhalangan, mengorganisasi kelas serta berkomukasi dengan mahasiswa tanpa harus terikat dengan jadwal kuliah di kelas. Disamping itu dosen dapat memberikan tugas dan langsung memberikan nilai kepada mahasiswa. Penyampaian pembelajaran 
dengan daring merupakan pembelajaran dengan memanfaatkan teknologi internet untuk meningkatkan lingkungan belajar dengan cakupan yang luas. Pembelajaran daring merupakan pembelajaran dengan memanfaatkan internet dalam pembelajaran untuk mengirimkan serangkaian solusi yang dapat meningkatkan pengetahuan dan keterampilan. Menurut (Sabran \& Sabara, 2019) Setiap metode pembelajaran harus mengandung rumusan pengorganisasian bahan pelajaran, strategi penyampaian, dan pengelolaan kegiatan dengan memperhatikan faktor tujuan belajar, hambatan belajar, karakteristik mahasiswa agar dapat diperoleh efektivitas, efesiensi, dan daya Tarik pembelajaran.

Mahasiswa dalam belajar membutuhkan motivasi yang merupakan suatu dorongan atau kekuatan menyebabkan mahasiswa mempunyai keinginan untuk melakukan kegiatan belajar. Dosen memiliki peranan penting dalam menumbuhkan motivasi belajar mahasiswa. Dosen dapat menciptakan pembelajaran yang menarik sehingga dapat menumbuhkan motivasi belajar mahasiswa. Media pembelajaran yang digunakan untuk membantu dosen menciptakan pembelajaran yang menarik. Pembelajaran saat ini, lebih diarahkan pada aktivitas modernisasi dengan bantuan teknologi canggih dengan harapan dapat membantu mahasiswa dalam mencerna materi perkuliahan secara interaktif, produktif, efektif, inspiratif, konstruktif, dan menyenangkan. Selain itu, mahasiswa juga diharapkan memiliki life skill dari aplikasi teknologi tersebut. Dengan adanya era teknologi yang semakin berkembang ini, maka program pembelajaran diarahkan untuk bisa memanfaatkan teknologi dengan lebih baik. Salah satu pemanfaatan teknologi adalah dengan mengases web. Tidak dipungkiri saat ini semua mahasiswa sudah memiliki smartphone jadi lebih mudah untuk mengakses di manapun dan kapanpun. Pemanfaatan pembelajaran online yang terus dikembangkan saat ini adalah menggunakan Learning Management System (LMS) (Nirfayanti \& Nurbaeti, 2019).

Aplikasi google classroom secara resmi diluncurkan pada Agusuts 2014 (Maulana, 2021). Sebuah aplikasi yang dapat menciptakan ruang kelas secara online sehingga dapat menjadi media penyampaian materi, pendistribusian dan pengumpulan tugas, dan melakukan penilaian terhadap tugas-tugas yang telah dikumpulkan oleh peserta didik. Selain itu, aplikasi ini menyediakan fitur untuk mengunggah bideo atau menautkan link video dari youtube dan terdapat forum diskusi sehingga dosen bisa membuka sebuah diskusi kelas seperti di Facebook yang dapat ditanggapi dan dikomentari (Kusuma et al., 2019).

Dosen dipermudah dalam menyampaikan materi yang tidak tergantung pada waktu dan tempat sehingga proses pembelajaran bisa kapan dan dimana saja, selain itu mampu menyimpan bahan ajar yang dapat diakses melalui smartphone dengan dukungan jaringan internet. Menurut (Daeng et al., 2017) menyatakan bahwa smartphone merupakan jenis perangkat yang banyak kita jumpai di masyarakat umum, sehingga perangkat ini sangat familiar bagi masyarakat dan digunakan oleh semua kalangan. Dengan adanya smartphone, guru mampu mengakses berbagai aplikasi sebagai pendukung belajar salah satunya yaitu google classroom. Google classroom adalah salah satu platform belajar daring pada smartphone maupun Personal Computer (PC) dengan koneksi internet. Sarana kegiatan belajar tanpa tatap muka langsung sehingga lebih efektif serta memudahkan karena tidak menggunakan kertas lagi. Selain itu (Gunawan \& Sunarman, 2018) menyatakan bahwa pengajar dapat menggunakan fitur pada aplikasi seperti assignment (tugas), granding (pengukuran), communication (komunikasi) mobile application (alpikasi telepon genggam), archive course (arsip program), privacy (privasi), time-cost (hemat waktu). Dengan demikian penggunaan Google Classroom pembelajaran akan lebih mudah dengan adanya interaksi antara mahasiswa dan dosen saat pembelajaran daring sehingga mahasiswa dapat belajar, bertanya, berpendapat, bertukar pikiran atau ide-ide, dan mengirimkan tugas dari jarak jauh melalui smartphone.

Berbagai media pembelajaran daring telah dimanfaatkan oleh pendidik atau dosen dalam proses belajar mengajar pada masa pandemi ini. Namun kita menyadari bahwa akplikasi dan media yang digunakan masih banyak kendala dan kekurangan, hal tersebut terlihat dari beberapa kasus yang dialami dosen dinama Ketika mengajar secara online hanya sekitar 50\% mahasiswa yang aktif belajar dan sementara 50\% lainnya tidak bisa dipastikan apakah masih mengikuti pelajaran atau malah melakukan kegiatan lain. Mahasiswa yang tidak aktif 
1939 Pengaruh Pembelajaran Daring Berbasis Google Classroom terhadap Hasil Belajar Mahasiswa Pendidikan Biologi-Rahmatia Thahir

DOI: https://doi.org/10.31004/edukatif.v3i4.1123

belajar karena belum terkontrol dengan baik dapat berakibat pada rendahnya hasil belajar yang diperoleh. Oleh karena itu, dosen sebagai pendidik perlu benar betul-betul memilih dan memanfaatkan media aplikasi yang inovatif dan efektif sehingga memberikan kontribusi positif terhadap hasil belajar mahasiswa sesuai dengan indikator capaian dan tujuan pembelajaran(Magfirah et al., 2020).

Adapun kelebihan google classroom yakni mudah digunakan, menghemat waktu, berbasis cloud, fleksibel, dan gratis. Hal ini yang menjadi pertimbangan bahwa aplikasi ini tepat digunakan untuk di sekolah. Meskipun masih memiliki kelemahan seperti tidak adanya layanan eksternal seperti bank soal secara otomatis dan obrolan secara pribadi antara guru untuk mendapatkan umpan balik. Selama ini penelitian tentang google classroom lebih dominan membahas tentang data persepsi mahasiswa, minat belajar, serta kemampuan atau keterampilan mahasiswa setelah pemanfaatnya dan belum banyak membahas tentang bagaimana hasil belajar kognitif siswa setelah pembelajaran dengan sepenuhnya memanfaatkan google classroom. Perbedaan penelitian ini dengan penelitian sebelumnya adalah bukan cuma untuk mengambil data saja tetapi betul-betul memanfaatkan google classroom tanpa menggunakan aplikasi lain sebagai penunjang dalam proses pembelajaran. Semua bentuk aktivitas baik itu komunikasi antara dosen dan mahasiswa terkait perkuliahan, diskusi antar mahasiswa tetang materi yang diberikan semuanya dilakukan di forum google classroom. Kemudian bentuk materi dan tugas yang diberikan bervariatif sehingga tidak membuat mahasiswa bosan dalam proses pembelajaran. Pada akhir dari perlakuan tersebut diharapkan hasil belajar mahasiswa menjadi lebih baik dari sebelumnya.

Penelitian sebelumnya yang telah dilakukan oleh (Iftakhar, 2016) dengan judul Google Classroom: What Works and How? Berisi mengenai bahwa google classroom membantu untuk memonitoring siswa untuk belajar. Guru dapat melihat seluruh aktivitas siswa selama pembelajaran, interaksi antara guru dan siswa terekam dengan jelas. (Suhada et al., 2020) melakukan penelitian tentang pembelajaran daring berbasis google classroom pada mahasiswa Pendidikan biologi selama masa pandemi COVID-19. Hasil penelitiannya menunjukkan bahwa penggunaan google classroom pada pembelajaran daring sudah cukup baik dan efektif. Berdasarkan pemaparan tersebut maka tujuan dari penelitian ini adalah untuk mengetahui apakah ada pengaruh pembelajaran daring berbasis Google Classroom terhadap hasil belajar mahasiswa Pendidikan biologi universitas Muhammadiyah makassar.

\section{METODE PENELITIAN}

Jenis penelitian ini adalah pre-experimental design. Menurut (Arikunto, 2010) menyatakan bahwa preexperimental design seringkali dipadang sebagai eksperimen yang tidak sebenarnya. Oleh karena itu sering juga disebut sebagai quasy experiment. Disebut demikian karena eksperimen jenis ini belum memenuhi peraturan-peraturan tertentu. Menurut (Sugiyono, 2014), disebut sebagai pre-experimental design karena metode ini belum merupakan ekperimen sengguh-sungguh. Karena masih terdapat variabel luar yang ikut berpengaruh terhadap terbentuknya variabel dependen. Jadi hasil eksperimen yang merupakan variabel dependen itu bukan semata-mata dipengaruhi oleh variabel independent. Hal ini dapat terjadi karena tidak adanya variabel control dan sampel tidak dipilih secara random. Variabel bebas (independent) dalam penelitian ini adalah pembelajaran daring berbasis google classroom, sedangkan variabel terikat adalah hasil belajar mahasiswa. Penelitian ini merupakan penelitian kuantitatif dengan desain penelitian one group pretest posttest design. Menurut (Arikunto, 2010) menyatakan bahwa one group pretest posttest design adalah kegiatan penelitian yang memberikan tes awal (pretest) sebelum diberikan perlakuan, setelah diberikan perlakuan barulah memberikan tes akhir (posttest). Rancangan desain penelitian ini terdiri dari satu kelompok yang telah ditentukan. Adapun desain penelitian menurut (Sugiyono, 2014) sebagai berikut.

\section{$\mathrm{O}_{1} \times \mathrm{O}_{2}$}

Edukatif : Jurnal Ilmu Pendidikan Vol 3 No 4 Tahun 2021 p-ISSN 2656-8063 e-ISSN 2656-8071 
1940 Pengaruh Pembelajaran Daring Berbasis Google Classroom terhadap Hasil Belajar Mahasiswa Pendidikan Biologi-Rahmatia Thahir

DOI: https://doi.org/10.31004/edukatif.v3i4.1123

Keterangan:

$\mathrm{O}_{1}=$ nilai pretest

$\mathrm{x}=$ pembelajaran daring berbasis google classroom

$\mathrm{O}_{2}=$ nilai posttest

Populasi dalam penelitian ini adalah seluruh mahasiswa Angkatan 2018 pada semester genap tahun akademik 2020-2021 terdiri dari kelas A, B, dan C dengan jumlah keseluruhan sebanyak 55 orang mahasiswa. Adapun sampel yang mewakili populasi dalam penelitian ini adalah kelas $\mathrm{C}$ sebanyak 20 orang mahasiswa sebagai kelas eksperimen. Teknik pengambilan sampel yang digunakan adalah purposive sampling. Dimana pengambilan sampel dengan pertimbangan tertentu.

Adapun instrument dalam penelitian ini adalah soal tes hasil belajar. Soal tes dalam bentuk essai sebanyak 10 nomor dengan tingkat koknitif C2 (memahami), C3 (mengaplikasikan), C4 (menganalisis). Teknik pengumpulan data yaitu dengan memberikan tes pada awal pertemuan (pretest) dan pada akhir pertemuan (posttest). Data yang diperoleh melalui tes tersebut kemudian dianalisis. Analisis penilaian hasil belajar menggunakan analisis deskriptif dan analisis inferensial dengan bantuan program SPSS versi 24.

\section{HASIL DAN PEMBAHASAN PENELITIAN}

Penelitian ini bertujuan untuk menguji pengaruh pembelajaran daring berbasis google classroom terhadap hasil belajar mahasiswa mata kuliah evolusi program studi Pendidikan biologi Universitas Muhammadiyah Makassar. Berdasarkan hasil analisis data secara deskriptif yang telah dilakukan menunjukkan nilai rata-rata hasil belajar mahasiswa berbeda pada saat sebelum dan sesudah dilakukan perlakuan. Dimana nilai rata-rata pretest sebesar 55 sedangkan nilai posttest sebesar 80, mengalami peningkatan setelah diterapkannya pembelajaran daring berbasis google classroom. Berikut disajikan tabel data pretest dan posttest hasil belajar mahasiswa.

Tabel 1. Hasil Belajar Mahasiswa Pada Saat Pretest Dan Posttest

\begin{tabular}{cccccc}
\hline \multirow{2}{*}{ Kategori } & \multirow{2}{*}{ Nilai } & Frekuensi & $\begin{array}{c}\text { Persentase } \\
(\boldsymbol{\%})\end{array}$ & Frekuensi & Persentase (\%) \\
\cline { 2 - 6 } & & & 0 & 3 & 15 \\
\hline Sangat baik & $>81$ & 1 & 5 & 14 & 70 \\
\hline Baik & $61-80$ & 9 & 45 & 3 & 15 \\
\hline Cukup & $41-60$ & 10 & 50 & 0 & 0 \\
\hline Kurang & $21-40$ & 0 & 0 & 0 & 0 \\
\hline Sangat kurang & $<20$ & 20 & 100 & 20 & 100 \\
\hline Jumlah & & & &
\end{tabular}

Berdasarkan tabel 1 diatas menunjukkan bahwa setelah perlakuan selesai maka semakin banyak mahasiswa yang berada pada kategori baik dan sangat baik dibandingkan sebelum diberi perlakukan. Hal ini disebabkan karena meskipun belajarnya dengan secara daring tetapi mahasiswa tetap bersemangat, tidak mengeluh dan juga tidak bosan dalam belajar. Peneliti selalu berusaha membangun suasana belajar yang menyenangkan, membagikan file materi yang variatif baik kadang dalam bentuk powerpoint (ppt), video, link youtube, dan artikel. Begitu pula dengan tugas yang diberikan bervariatif kadang dalam bentuk tugas yang didiskusikan dalam kelompok yang dilakukan pada bagian forum google classroom tetap dengan koordinasi dari dosen sebagai peneliti. Kemudian melaksanakan kuis dengan cara memberikan pertanyaan dan setiap mahasiswa mendapat kesempatan yang sama, dan akan menjadi pertanyaan rebutan jika mahasiswa tersebut tidak mampu menjawab atau jawabannya kurang tepat. Dan juga diberikan tugas untuk membuat ppt dengan 
1941 Pengaruh Pembelajaran Daring Berbasis Google Classroom terhadap Hasil Belajar Mahasiswa Pendidikan Biologi-Rahmatia Thahir

DOI: https://doi.org/10.31004/edukatif.v3i4.1123

memunculkan audio visualnya kemudian dikirim ke kolom Assigment dari google classroom semuanya dilakukan selama dalam proses pembelajaran.

Pembelajaran daring tidak berbeda dengan pembelajaran tatap muka di kampus dari segi penilaian, tugas juga masih ada walaupun tidak seperti pada waktu belajar langsung di kelas. Siswa juga tetap mengerjakan tugas yang diberikan dosennya untuk dikerjakan sebagai pengambilan nilai yang bisa dilakukan setiap hari namun tidak setiap hari diberikan. Pemberian tugas juga harus memperhatikan situasi dan kondisi pembelajaran jika memungkinkan maka silahkan diberi tugas sesuai dengan materi. Pembelajaran daring yang diterapkan lebih cenderung pada bentuk penugasan via aplikasi. Mahasiswa diberikan tugas-tugas untuk diselesaikan kemudian dikoreksi oleh guru sebagai bentuk penilaian dan diberikan komentar sebagai bentuk evaluasi (Syarifudin, 2020). Untuk menghidari mahasiswa bosan dalam belajar dan selalu bersemangat dalam belajar maka diberikan perlakuan yaitu dengan memberikan video animasi yang menarik perhatian mahasiswa pada saat pembelajaran berlangsung dengan membagikan link nya pada platform google classroom. Dan dalam pembelajaran daring diberikan motivasi dan semangat belajar meskipun menyapa mereka hanya secara virtual (Yunitasari \& Hanifah, 2020).

Guru selalu meberikan motivasi kepada mahasiswa pada saat pembelajaran daring berlangsung agar siswa itu tidak jenuh, tidak lemas, dan minat belajar mahasiswa tetap ada. Dan juga memperhatikan siswa sebagaimana mestinya seperti di kelas jika mahasiswa tidak memahami materi pembelajaran maka dosen membantu mahasiswa yang mengalami kesulitan belajar tersebut sehingga mereka bisa paham. Menurut (Yunitasari \& Hanifah, 2020), ada beberapa langkah agar siswa tetap semangat dan tidak bosan dalam belajar diantaranya: Menyusun tujuan pembelajaran sesuai dengan kemampuan mahasiswa, mampu membuat relevansi antara materi pembelajaran dengan kehidupan nyata siswa, mampu menghubungkan pembelajaran dengan minat belajar siswa, memberikan kebebasan bagi siswa untuk membuat keputusan atau pilihan sendiri, serta menunjukkan sikap suka dan antusias guru saat mengajar.

Teknik analisis data secara inferensial digunakan untuk mengetahui pengaruh variabel bebas (pembelajaran daring berbasis google classroom) terhadap variabel terikat (hasil belajar) dalam penelitian ini adalah analisis Independent Sample T Test (uji-t). sebelum dilakukan uji-t terlebih dahulu dilakukan uji prasyarat yang meliputi uji normalitas dengan menggunakan analisis One Sample Kolmogorov-Smirnov Test dan uji homogenitas menggunakan Levene's Test of Equality of Error Variances dengan bantuan SPSS 24. Adapun hasil analisis disajikan pada tabel dibawah ini.

Tabel 2. Ringkasan Hasil Uji Prasyarat dan Uji Hipotesis nilai hasil belajar

\begin{tabular}{llc}
\hline No. & Komponen & Sig. \\
\hline 1 & Uji Normalitas (One-Sample Kolmogorov Smirnov Test) & .650 \\
2 & Uji Homogenitas (Levene's Test of Equality of Error) & .374 \\
3 & Uji t (Independent-Sample T Test) & .001 \\
\hline
\end{tabular}

Berdasarkan hasil uji normalitas diperoleh nilai sig. 0,650 $>\alpha=0,05$ menunjukkan bahwa data berdistribusi normal. Hasil uji homogenitas diperoleh nilai sig. 0,374 $>\alpha=0,05$ menunjukkan bahwa data bersifat homogen. Berdasarkan kedua uji tersebut maka data memenuhi syarat untuk dilakukan uji hipotesis. Uji hipotesis dengan menggunakan analisis Independent Sample T Test dan diperoleh nilai signifikasi $\mathrm{p}=$ $0,001<\alpha=0,05$. Ini berarti $\mathrm{H}_{0}$ ditolak dan $\mathrm{H}_{1}$ diterima. Dapat disimpulkan bahwa ada pengaruh pembelajaran daring berbasis google classroom terhadap hasil belajar mahasiswa Pendidikan biologi Universitas Muhammadiyah Makassar. Hal ini disebabkan karena mahasiswa berpartisipasi aktif dalam proses pembelajaran. Mereka mampu menyediakan sumber informasi berupa artikel, dan video-video diskusi yang terkait dengan mata kuliah evolusi selain dari yang diberikan oleh dosen/peneliti. Kemudian materi ajar yang diberikan oleh dosen dalam bentuk powerpoint, video dari youtube, URL, serta mengirimkan soal-soal kuis 
kepada mahasiswa maka mahasiswa aktif melakukan diskusi. Beberapa mahasiswa memberikan pertanyaan, ada yang menjawab pertanyaan, dan ada juga yang menambahkan jawaban yang diberikan oleh mahasiswa lain. Kemudian mahasiswa juga menyelesaikan dan mengirimkan tugas sesuai dengan waktu tenggat yang diatur oleh dosen pada platform google classroom ini menunjukkan bahwa sudah terbentuk sifat bertanggungjawab dan disiplin dalam diri mahasiswa. Sesuai dengan hasil peneltian yang telah dilakukan oleh (Sukmawati, 2020) yang menyimpulkan bahwa google classroom merupakan metode yang tepat yang dapat digunakan dalam pembelajaran online yang melibatkan dosen dan mahasiswa secara aktif dalam proses pembelajaran. Mempermudah proses pembelajaran dimana pun mahasiswa berada tidak terbatas pada ruang kelas dan buku yang tersedia, Dengan google classroom pembelajaran dilakukan secara fleksibel tidak terbatas waktu dan tempat. Semua mahasiswa dapat mengikuti pembelajaran dimanapun berada. Melalui google classroom mahasiswa dapat membaca materi pembelajaran dan menyimpulkan pembelajaran yang tidak menggunakan kertas. Sehingga dapat menghemat waktu, tenaga dan alat pendukung pembelajaran lainnya, hal ini memberikan pengalaman baru bagi mahasiswa Pendidikan biologi Universitas Muhammadiyah Makassar.

Menurut (Salamah, 2020) adapun kelebihan menggunakan aplikasi google classroom yaitu mudah digunakan: desain google classroom sengaja dibuat untuk menyederhanakan instruksional dan opsi yang digunakan untuk tugas pengiriman. Berbasis cloud: menghadirkan teknologi yang lebih professional dan otentik untuk digunakan dalam lingkungan belajar karena aplikasi google mewakili sebagain besar alat komunikasi perusahaan berbasis cloud yang digunakan di seluruh Angkatan kerja professional. Fleksibel: aplikasi ini mudah diakses dan dapat digunakan oleh instruktur dan peserta didik. Ranah seluler: google classroom dirancang agar responsif, mudah digunakan pada perangkat mobile manapun.

Adapun beberapa manfaat proses pembelajaran dengan menggunakan google classroom menurut (Sukmawati, 2020) sebagai berikut: (1) proses persiapan perkuliahan relatif lebih mudah dikarenakan mahasiswa dapat menyiapkan kelas dan mengundang mahasiswa. Dihalaman tugas kelas mereka dapat berbagi informasi tugas, pertanyaan, dan materi; (2) efektif dan efisien disebabkan pendidika dapat mebuat kelas, memberikan tugas, dan berkomunikasi melalui media ini; (3) pengelolaan yang lebih baik dimana mahasiswa dapat melihat tugas di halaman tugas, di keleder kelas. Semua menerima materi tersebut dan dapat tersimpan dalam folder google drive. (4) penyempurnaan komunikasi disebabkan mahasiswa dapat berbagi materi antar satu sama lain melalui media email. Pendidik juga dapat melihat dengan cepat mahasiswa yang telah atau belum menyelesaikan tugas, dan ada email yang masuk ke email pendidik jika mahasiswa telah mengirimkan tugas; (5) terjangkau dan aman. Google classroom disediakan gratis untuk sekolah, lembaga, dan perorangan. Media ini tidak berisi iklan sehingga tidak terdapat gangguan pada proses pembelajaran.

Namun tidak bisa dipungkiri bahwa perubahan pembelajaran yang biasanya dilakukan secara tatap muka di kelas sekarang semuanya dilakukan secara daring. Sehingga kita tidak bisa membimbing mahasiswa secara persuasif ketika mahasiswa mengalami kendala dalam belajar. Namun setiap mahasiswa harus mampu belajar membiasakan dengan suasana seperti itu. Menurut (Jatira, 2021) belajar pembiasaan adalah proses pembentukan kebiasaan baru atau perbaikan kebiasaan-kebiasaan yang telah ada terhadap sesuatu atau kondiri yang baru. Kebiasaan belajar dapat diartikan sebagai cara untuk menetapkan diri pada waktu menerima pembelajaran, membaca buku, mengerjakan tugas, dan mengatur waktu untuk mengelesaikan kegiatan. Sehingga membentuk sikap dan kebiasaan baru yang bersifat positif bagi diri mahasiswa. Hal ini sangat berguna bagi perkembangan ilmu kedepannya karena mahasiswa lebih terbuka pemikirannya dan mudah memperbaharui pengetahuan mereka. 
1943 Pengaruh Pembelajaran Daring Berbasis Google Classroom terhadap Hasil Belajar Mahasiswa Pendidikan Biologi-Rahmatia Thahir

DOI: https://doi.org/10.31004/edukatif.v3i4.1123

\section{KESIMPULAN}

Berdasarkan hasil penelitian dapat disimpulkan bahwa ada pengaruh pembelajaran daring berbasis Google Classroom terhadap hasil belajar mahasiswa.program stidu Pendidikan biologi Universitas Muhammadiyah Makassar. Adapun nilai rata-rata pretest sebesar 55 sedangkan nilai rata-rata pada saat posttest sebesar 80. Hasil uji hipotesis dengan menggunakan analisis Independent Sample T Test dan diperoleh nilai signifikasi $\mathrm{p}=0,001<\alpha=0,05$. Berarti $\mathrm{H}_{0}$ ditolak dan $\mathrm{H}_{1}$ diterima. Saran untuk penelitian lebih lanjut agar membandingkan pembelajaran yang menggunakan google classroom dengan pembelajaran dengan menggunakan aplikasi lain yang sama-sama tidak menggunakan camera atau video pada saat proses pembelajaran.

\section{DAFTAR PUSTAKA}

Arikunto, S. (2010). Prosedur Penelitian Suatu Pendekatan Praktek. Jakarta: Rineka Cipta.

Daeng, I. T. M., Mewengkang, N. ., \& Kalesaran, E. R. (2017). Penggunaan Smartphone Dalam Menunjang Aktivitas Perkulihan Oleh Mahasiswa Fispol Unsrat Manado. E-Journal “Acta Diurna," 6(1), 1-15. Https://Ejournal.Unsrat.Ac.Id/Index.Php/Actadiurnakomunikasi/Article/View/15482/15023

Durahman, D. (2020). Pemanfaatan Google Classroom Sebagai Multimedia Pembelajaran Bagi Guru Madrasah Pada Diklat Di Wilayah Kerja Kemenag Kabupaten Cianjur. Tatar Pasundan: Jurnal Diklat Keagamaan, 12(34), 215-221. Https://Doi.Org/10.38075/Tp.V12i34.71

Gunawan, F. I., \& Sunarman, S. G. (2018). Pengembangan Kelas Virtual Dengan Google Classroom Dalam Keterampilan Pemecahan Masalah (Problem Solving) Topik Vektor Pada Siswa Smk Untuk Mendukung Pembelajaran. Prosiding Seminar Nasional Etnomatnesia, 340-348. Https://Jurnal.Ustjogja.Ac.Id/Index.Php/Etnomatnesia/Article/View/2334/1296

Iftakhar, S. (2016). Google Classroom: What Works And How? Journal Of Education And Social Sciences, 3, 12-18. Http://Jesoc.Com/Wp-Content/Uploads/2016/03/KC3_35.Pdf

Jatira, Y. (2021). EDUKATIF: JURNAL ILMU PENDIDIKAN Fenomena Stress Dan Pembiasaan Belajar Daring Dimasa Pandemi Covid-19. Jurnal Ilmu Pendidikan, 3(1), 35-43. Https://Doi.Org/Https://Doi.Org/10.31004/Edukatif.V3i1.187

Kusuma, A. B., Astuti, W., \& Setyawan, C. E. (2019). Analisis Penerapan Media Pembelajaran Bahasa Arab Berbasis Aplikasi Google Classroom DI Sekolah Tinggi Agama Islam Masjid Syuhada (STAIMS) Yogyakarta. Jurnal Komunikasi Dan Pendidikan Islam, 1(8), 151-180. Https://Doi.Org/Https://Doi.Org/10.36668/Jal.V8i2.120

Magfirah, N., Nurdiyanti, N., Anisa, A., \& Thahir, R. (2020). Peranan Edmodo Sebagai Alternatif Dalam Pembelajaran Daring. Jurnal Biotek, 8(2), 123. Https://Doi.Org/10.24252/Jb.V8i2.14000

Maulana, H. A. (2021). Persepsi Mahasiswa Terhadap Pembelajaran Daring Di Pendidikan Tinggi Vokasi: Studi Perbandingan Antara Penggunaan Google Classroom Dan Zoom Meeting. Edukatif: Jurnal Ilmu Pendidikan, 3(1), 188-195. Https://Doi.Org/10.31004/Edukatif.V3i1.259

Nande, M., \& Irman, W. A. (2021). Penerapan Model Pembelajaran Blended Learning Dalam Meningkatkan Hasil Belajar Siswa Sekolah Menengah Kejuruan. Edukatif: Jurnal Ilmu Pendidikan, 3(1), 180-187. Https://Doi.Org/10.31004/Edukatif.V3i1.240

Nirfayanti, N., \& Nurbaeti, N. (2019). Pengaruh Media Pembelajaran Google Classroom Dalam Pembelajaran Analisis Real Terhadap Motivasi Belajar Mahasiswa. Proximal Jurnal Penelitian Matematika Dan Pendidikan Matematika, 2(1), 50-59. Https://E-Journal.My.Id/Proximal/Article/View/211

Nurdiyanti, N., \& Jannah, M. (2021). Pengaruh Pembelajaran Online Berbantuan Google Classroom Terhadap Hasil Belajar Siswa Pada Materi Sistem Peredaran Darah Pada Manusia. Jurnal Riset Dan Inovasi Pembelajaran, 1(1), 75-84. Https://Doi.Org/Https://Doi.Org/10.51574/Jrip.V1i1.21 
1944 Pengaruh Pembelajaran Daring Berbasis Google Classroom terhadap Hasil Belajar Mahasiswa Pendidikan Biologi - Rahmatia Thahir

DOI: https://doi.org/10.31004/edukatif.v3i4.1123

Sabran, \& Sabara, E. (2019). Keefektifan Google Classroom Sebagai Media Pembelajaran. Prosiding Seminar Nasional Lembaga Penelitian Universitas Negeri Makasar, 122-125. Https://Ojs.Unm.Ac.Id/Semnaslemlit/Article/Download/8256/4767+\&Cd=2\&Hl=Id\&Ct=Clnk\&Gl=Id

Salamah, W. (2020). Deskripsi Penggunaan Aplikasi Google Classroom Dalam Proses Pembelajaran. Jurnal Penelitian Dan Pengembangan Pendidikan, 4(3), 533-538. Https://Doi.Org/Http://Dx.Doi.Org/10.23887/Jppp.V4i3.29099

Su'uga, H. S., Ismayati, E., Agung, A. I., \& Rijanto, T. (2020). Media E-Learning Berbasis Google Classroom Untuk Meningkatkan Hasil Belajar Siswa SMK. Jurnal Pendidikan Teknik Elektro, 9(3), 605-6010. Https://Ejournal.Unesa.Ac.Id/Index.Php/Jurnal-Pendidikan-Teknik-Elektro/Article/View/36253

Sugiyono. (2014). Metode Penelitian Kuantitatif Kualitatif Dan R\&D. Bandung: Alfabeta.

Suhada, I., Kurniati, T., Pramadi, A., \& Listiawati, M. (2020). Pembelajaran Daring Berbasis Google Classroom Mahasiswa Pendidikan Biologi Pada Masa Wabah Covid-19. Digital Library UIN Sunan Gunung Jati.

Sukmawati, S. (2020). Implementasi Pemanfaatan Google Classroom Dalam Proses Pembelajaran Online Di Era Industri 4 . $0 . \quad$ Jurnal Kreatif Online, $8(1), \quad 39-46$. Http://Jurnal.Untad.Ac.Id/Jurnal/Index.Php/JKTO/Article/View/15680

Syarifudin, A. S. (2020). Impelementasi Pembelajaran Daring Untuk Meningkatkan Mutu Pendidikan Sebagai Dampak Diterapkannya Social Distancing. Jurnal Pendidikan Bahasa Dan Sastra Indonesia Metalingua, 5(1), 31-34. Https://Doi.Org/10.21107/Metalingua.V5i1.7072

Yunitasari, R., \& Hanifah, U. (2020). Pengaruh Pembelajaran Daring Terhadap Minat Belajar Siswa Pada Masa COVID 19. Edukatif: Jurnal Ilmu Pendidikan, 2(3), 232-243. Https://Doi.Org/10.31004/Edukatif.V2i3.142 